\title{
Different Approaches About the Ethnic Origin of the Druze
}

\author{
Jihan Farhoud ${ }^{1,2}$ \\ ${ }^{1}$ (History) Druze Sector, Pedagogical Secretariat, Ministry of Education, Israel \\ ${ }^{2}$ BABES-BOLYI Faculty of History, BABES-BOLYI University, Cluj-Napoca, Romania
}

\section{Email address:}

Jihan61@hotmail.com

\section{To cite this article:}

Jihan Farhoud, Different Approaches About the Ethnic Origin of the Druze. History Research. Vol. 9, No. 1, 2021, pp. 74-77. doi: 10.11648/j.history.20210901.19

Received: January 3, 2021; Accepted: March 18, 2021; Published: April; 7, 2021

\begin{abstract}
Around one thousand years have passed since the Druze appeared on the stage of history as bearers of a religion and a philosophy. In the year 1043, at the end of the period of preaching and dissemination, Druze clans were widely dispersed over a broad area that extended from North Africa in the west to India in the East. Since they were a minority, and because of opposition to the new religion, they were persecuted by rulers and by other nations, and many of them died out or were forced to abandon their religion and assimilate into other societies. Historical research has no final and absolute answers regarding the ethnic origins of the Druze. In this article, I will present the various research approaches to their ethnic origins. The first attempts to investigate Druze origins were made by European travelers and researchers, mainly French and English, and also by Philip Hitti, an American scholar of Lebanese origin. The Arab researchers who dealt with this subject are divided in their opinion. Some claim that the Druze are of Arab origin, while others assert that the Druze are descendants of ethnic groups that had once inhabited the region and had died out in the course of history. I will also present the position of some Arab historians and researchers and Israeli Druze of the modern period regarding the origins of the Druze now living in the State of Israel, in Syria, in Jordan, in Lebanon, and in the diaspora.
\end{abstract}

Keywords: Approaches, Origins, Druze, Middle East, Arabic Tribes, Arabian Peninsul

\section{Introduction}

"The Druzes of Syria are unique community. Like social fossils in an alien environment, this people has survived for hundreds of years in that land rightly described as a "Babel of tongues" and a "museum of nationalities" [1].

The Druze religion was founded in Egypt during the reign of Al-Hakim bi-Amr Allah, "Druzism dates back to the year 1017 in Egypt under the leader Caliph alHakim who was a central part of the religion's development. He later came to recognize the religion nationally and began to promote religious freedom, an important liberty for followers of such a small religious minority [2].

Al-Hakim was the sixth Fatimid Calip, Talea' Amin claims that the Fatimid caliph Al-Hakim bi-Amr Allah was the fifth caliph [3], who ruled during the years 996-1021 CE. He received sovereignty after the death of his father before having reached the age of twelve. During his ruling period, the Fatimids controlled the entire area of Syria. [4]. The Druze religion was disseminated during the years 1017-1043 among the Isma'ilis, the second largest faction in the Shia branch of Islam who were willing to accept it more than other Muslims [5].

The Druzes have no such clear record to show regarding their origin as a people and as a sect. Their ethnographical origins, no less than their ritual practices and religious beliefs, are shrouded in mystery. Appearing for the first time on the pages of history at Wādi-al-Taym near Mt. Hermon in antiLebanon, as professors of the divinity of the sixth Fātimite Caliph in Cairo (996-1020 A. D.), the Druzes have lived their semi-independent lives secluded in their mountain fastness of Lebanon, unmindful of the progress of the world around them, and almost entirely forgotten by the outside world [1].

the Druze numbered more than 2,000,000 in the early $21 \mathrm{st}$ century and live mostly in Syria (40-50\%), Lebanon (thirty to forty percent), Israel 141,000 [6], at the end of 2017 (one point six percent of the population), Jordan (one or two percent). Big communities of emigrant Druze also are living outside the Middle East in West Africa, Australia, Canada, Europe, Latin America, and the United States. The Druze have a flag including five colors, which represent the five 
prophets [7].

Throughout the centuries the origins of the Druze, both ethnic and religious, have never ceased to be the subject of speculation. The suggestions about their racial origins have ranged through the Samaritans, the Cuthites and the Hivites to the French, the British and the Tibetans [8]. Although very little is known of the Druze religion, since the actual practices and the scriptures [9]. Several hypotheses have been proposed to explain the history of contemporary Druze based on historic, archaeological and linguistic evidence. These hypotheses espouse that Druze emerged from Arabian tribes such as the Tanukhs or Itureans, from Persian populations [10].

This question is particularly challenging given the Druze's original nomadic lifestyle and the development, over time, of their esoteric religion that incorporates Isma'ilism Islam, Judaism, Zoroastrian, Hindu, Christian, Neo-Platonic and Persian influences. [11].

\section{Distribution of the Druze in the Middle East and in the World}

The period of Druze religious preaching ended in the year 1043, after which new adherents were no longer admitted. By this time the Druze religion had become widespread, ranging from Northern Africa in the west to India in the east. Since they were a minority and because of opposition to the new religion, they were persecuted by rulers and by other nations, and many of them were either eliminated or were forced to abandon their faith and to be assimilated among other societies [12].

Today, most of the Druze live in the Middle East. They are centered in various geographical enclaves within the area of four states: Syria, Lebanon, Israel and Jordan.

\subsection{Approaches on Druze Origins}

Researchers lay emphasis on the ethnic origins of the converts to the Druze religion during the first half of the $11^{\text {th }}$ century CE. There is no doubt that ethnic origin is of importance in the historical development of every human group.

Historical research has no final and absolute answer regarding the ethnic origins of the Druze. Muslim and Christian chronicle writers who lived during the early centuries of the dissemination of the Druze religion, made no reference to this question.

Other researchers ascribe various origins to the Druze. French scholars claim that the Druze are descendants of the Crusaders and grandchildren of the French count De Dreux, This claim can be refuted because the First Crusade which began in the year 1096 occurred two hundred years after the Druze had reached their place of settlement in the Middle East [13].

Twelve Arab tribes accepted Islam and fought alongside the Muslim warriors until they accepted the new Druze religion which they heard about from preachers sent from
Egypt by the Fatimid caliph Al-Hakim bi-Amr Allah.

The dissemination of the Druze religion also occurred in the area of Palestine. Salman Falah mentions that one of the centers for the dissemination of the religion was in Safed (a city in the northern aeea of Israel). He adds that there were other stages in the settlement of the Druze in the Land of Israel, in the $16^{\text {th }}$ and $17^{\text {th }}$ centuries, during which there was a strong movement of Druze migrating from Lebanon to Palestine [14].

Arab historians of the $13^{\text {th }}-17^{\text {th }}$ centuries who wrote about the Druze were interested only in their religion and customs, as for example, Talea' in 1967 [15]. The first attempt to investigate the origins of the Druze was by European travelers and researchers, mainly French and English.

Arab historians and researchers believe that the Druze are of pure Arab origins, while others disagree with this opinion. In spite of the controversy over the ethnic origins of the Druze, their attitude of the government towards them is influenced mainly by their religious adherence and less by their ethnic origins. The reason for this is perhaps because the Druze did not doubt their affiliation with the Arab nation, although in practice they gave it less consideration and did not have the kind of Arab consciousness such as that of their Muslim neighbors [16]. Arab researchers are in disagreement. Some of them claim that the Druze are of Arab origin and others claim that the Druze are descendants of ethnic groups who once lived in the region and had died out in the course of history, or attribute their origins to be Persian, Turkish, Indian and even European.

Talea' claims that the Druze who are now settled in parts of Syria, Lebanon and Israel, had already dwelt here even before they acquired their religion [17]. The historian, Philip Hitti, asserts that the Druze invented an Arab origin for themselves for the sake of taqiyya (Dissimulation; a practice that permits members of a community to adopt the outward forms of other religions in order to protect their lives while inwardly maintaining their real faith. A practice adopted by the Druze and commonly employed by members of the community and especially its political leadership in times past when it was deemed necessary to please the ruling Sunni establishment), among the surrounding society [18], or through a desire for dignity within a society of ancient origins.

\subsection{Approaches in the Research on Druze Origins}

A study carried out by the Druze historian Kais Firro distinguished three approaches in the research on Druze origins:

An approach based on the Druze religion and the origins of the founders of the religion and its dissemination.

An approach based on a study of the migration movements of early tribes in the Middle East, mainly those that settled in Southern Lebanon during the $11^{\text {th }}$ century - a region where the Druze religion began to be disseminated.

An approach based on anthropometric studies by anthropologists who examined the skeletons of ancient people in Lebanon [19]. 
The first approach can be found in Philip Hitti, who claims that the Druze are a mixture of Persians, Kurds, Iraqis, and Arabs, on the basis of three major factors:

The founders of the Druze religion and its disseminators were Persians in origin.

Some of the Druze religious lexicon is of Persian origin.

The feudal families that ruled the Druze in the course of history were of Kurdish and Persian origin or of Arab tribes who had resided in Persia before they settled in Lebanon [20].

On the other hand, Martin Sprengling [21] proved that the religious words and terms that Hitti considered as Persian, had actually originated in the Arabic language, and that the terminology of the Druze religion was derived from the Persian language as well as from the ancient Syrian and Aramaic languages [22].

Two English researchers, Bell and Hogarth, claim that the Druze are a mixture of Arabs from Southern Arabia and the mountain dwelling Aramaeans [23].

The second approach can be found in Najlaa Abu-Izzeddin who reached the conclusion that the Druze and their neighbors were of Arab origin. According to her, since ancient times Greater Syria was the place for the encounter of peoples and cultures because of its geographical location, although most of its population came from the Arabian Peninsula. There were tribes seeking for arable lands in the area of Fertile Crescent long before the Arab Conquest in the $7^{\text {th }}$ century [24]. Basing herself on the research of the anthropologist Carleton Coon, she concluded that the Druze belong to the Brachycephlic race and to the Semitic race that spread into Syria in the wake of the migrating Arab tribes from the northern part of the Arabian Peninsula [25].

The third approach in the research on Druze origins is based on the conclusions of researchers and anthropologists who examined the skeletons of ancient Druze and Lebanese.

Arries and Kappers concluded that the Druze and their Muslim neighbors belong to the same race. On the other hand, Lushan and Lamartine did not find any link between the origin of the Druze and the origin of their Arab neighbors. In their view, the Druze are the remnants of the Hittites [26].

Most of the Druze researchers believe that the Druze are of pure Arab origin. They base this claim on the Druze chronicles of ancestral families. Firro disproved this claim because the Druze chronicles such as that of Salah ibn Yihya "Taareech Beirut" (History of Beirut), of Muhammad Malik al-Asharfani " O'mdat El-E'rfan", and the Arsalanic chronicle called, "El Sejel El-Arsilany" [27], were written at a later period.

In our times, Druze leaders and intellectuals believe that most of those who accepted the Druze religion were the twelve Arab tribes which migrated to Syria before the rise of Islam and also after it. Zaher Eddin also claims that the Druze go back in their origins to the twelve Arab tribes that settled in the region North West of Syria, from the time of the development of Islam and its conquests. At a later stage they went over to settle in Lebanon [28]. These tribes reached their place of settlement two hundred years before the birth of the Druze religion in Egypt. This view cannot be either verified or refuted, and we also cannot examine whether this view was invented by the Druze as a means to preserve their existence vis-à-vis the surrounding society.

It is important to note that this view was of great importance in the development of Druze identity because it was embedded within the consciousness of the Druze and helped them to become integrated within Arab Muslim society, especially during the modern period when Arab nationalism began to appear in Greater Syria. The Druze made use of this consciousness to integrate themselves in the political life of Syria and Lebanon.

Salman Falah claimed that the Druze living today originated in the Arabian Peninsula. Some of them came from the northern part of the Arabian Peninsula, and some of them came from the region of Yemen in the southern part of the peninsula [29].

In addition to these approaches, there are other explanations that are less acceptable to historians:

Two English travelers, Pococke and Maundrell claimed that the Druze were remnants of the French Crusader army under the command of De Dreux and who disappeared in the Shouf Mountains in Lebanon [30].

The traveler Camarvon wrote in 1860 that the Arab conquerors, the Kurds, the Bedouin, and others combined together to create the Druze.

Hitti noted that he heard many Druze in Lebanon who claim that they are of the yellow race; Hitti also claims that heard Lebanese Druze saying that they were related by blood to the British [31].

The English Adler of the $18^{\text {th }}$ century attributed the Druze to the tribe of Derusai - one of the ancient tribes of Median [32].

\section{Conclusion}

During the course of history, the Druze developed a consciousness of themselves as being of pure Arab origins, and that except for their religious cult, their spiritual and material culture was common with all the population of Greater Syria.

The Druze speak with a Syrian accent, their social organization is based on clans, as is the common situation for all those living in Greater Syria. From a cultural viewpoint, the Druze have many characteristics that resemble those of their neighbors. All of them speak Arabic. Therefore Druze leaders, intellectuals and historians in Lebanon and Syria tend to accept the claim that they belong to the twelve Arab tribes which arrived in Syria before the Islamic period and afterwards [33].

On the other hand, most of the Druze intellectuals in the State of Israel emphasize that their religious faith has existed since the creation of Adam.

It appears that the question of the ethnic identity of the Druze is not clear, and that historical research does not have a final and absolute answer in this matter.

The Druze Historians believe that the Druze are Arabs because of their ethnic affiliation with the twelve Arab tribes 
who came from the Arabian Peninsula to settle in the region of Greater Syria which included Lebanon, Syria and Palestine. The Arabic language is the language spoken by the Druze, and it is also the holy language in which their sacred books are written. In the eyes of the researchers who hold this view, it testifies to their ethnic Arab identity.

\section{References}

[1] Philip Hitti, The Origins of the Druze People \& Religion, New York: Ams press, 1966, p. 1.

[2] Aridi, Naim. "The Druze in Israel: History \& Overview." Jewish Virtual Library, 10 Sept. 2017, www.jewishvirtuallibrary.org/history-and-overview-of-theisraelidruze.

[3] Amin Talea', The Origins of the Al Almwahidun Al-Druze, (Beirut: Al Majles El Durzi, 1979), p. 46.

[4] Najlaa Abu Izzeddin, Druze in History (Beirut: The Education Home for Millions, 1985), pp. 95-96 [Arabic]

[5] The Druze in Israel, The Druze Research Section, University of Haifa, No. 6 (1982).

[6] Central of statistics, statistical data from 20/4/2018, Jerusalem, Israel.

[7] Jihan Farhoud, The Druze Minority in The Middle East: A Case study of the Druze in Israel, Casa Cărții de Ştiință, ClujNapoca, 2020, p. 3-4.

[8] David Bryer, The origins of the Druze religion, Der Islam, volume 52, issue 1, 2009.

[9] Hourani, A. A history of the Arab peoples: Updated edition (Faber \& Faber, 2013).

[10] Scarlett Marshall, Ranajit Das, Mehdi Pirooznia\& Eran Elhaik, Reconstructing Druze population history, volume 6, Article number: 35837, 2016, Scientific Reports

[11] Philip Hitti, The Oigins of the Druze People \& Religion with extracts from their sacred writings, Columbia University press, 1928.

[12] Najlaa Abu Izzeddin, Druze in History (Beirut: The Education Home for Millions, 1985), pp. 16 [Arabic]

[13] Amin Talea', The Origins of the Al Almwahidun Al-Druze, (Beirut: Al Majles El Durzi, 1979), p. 15.

[14] Salman Falah, History of the Druze in Israel (Jerusalem: Prime Minister Office, Arabs and Druze Consultant Office, 1974), p. 11.
[15] Amin Talea', The Origins of the Al Almwahidun Al-Druze (Beirut: Al Majles El Durzi, 1967).

[16] Salman Falah, History of the Druze (Ramat Gan: Bar Ilan University, 1989), p. 15-16 [Hebrew].

[17] Amin Talea', The Origins of the Al Almwahidun Al-Druze, (Beirut: Al Majles El Durzi, 1979), p. 13.

[18] Philip Hitti, The Origins of the Druze People \& Religion, New York: Ams press, 1966, p. 23.

[19] Kais Firro, A History of the Druzes (Leiden: Brill, 1992), p. 18.

[20] Philip Hitti, The Origins of the Druze People \& Religion, New York: Ams press, 1966, p. 18-22.

[21] Martin Sprengling, "The Berlin Druze Lexiooci", A. J. S. L. LVI, 1939, pp. 388-414.

[22] Kais Firro, A History of the Druzes (Leiden: Brill, 1992), p. 18-19.

[23] Najlaa Abu Izzeddin, The Druze: A New Study of their History, Faith and Society, Leiden, 1984, p. 10.

[24] Najlaa Abu Izzeddin, The Druze: A New Study of their History, Faith and Society, Leiden, 1984, p. 6-9.

[25] Najlaa Abu Izzeddin, The Druze: A New Study of their History, Faith and Society, Leiden, 1984, p. 4-6.

[26] Philip Hitti, The Origins of the Druze People \& Religion, New York: Ams press, 1966, p. 19.

[27] Shakib Arsenal, Deewan El-Shakik, (Beirut: D. N. 1935) [Arabic].

[28] Salih Zaher-Eddin, History of the Muslem Al Muwahidun Al Druze (Katar: The Arabic Center for Research and Documentation, 1994), p. 78 [Arabic].

[29] Salman Falah, The Druze in the Middle East (Jerusalem: Ministry of Defense, 2000), p. 22 [Hebrew].

[30] Robert Betts, The Druze (New Haven \& London: Yale University Press, 1988), p. 25.

[31] Philip Hitti, The Origins of the Druze People \& Religion, New York: Ams press, 1966, p. 14-17.

[32] Salih Alshech, Druze Identity, MA. Thesis, Tel Aviv University, 1978, pp. 45-149 [Hebrew]; Salih Alshech, A History of the Druze (Jerusalem: Ministry of Defense, 1989), p. 15. [Hebrew]

[33] Amin Talea', The Origin of the Monotheistic Druze, Beirut: Al Majles El Durzi, 1973. (in Arabic) 